\title{
Correspondence
}

(see go.nature.com/famkkn; in Portuguese). In defiance of European Union practice, more than $90 \%$ of these early-career scientists are currrently classed as 'advanced students' and funded by student scholarships.

Some institutions are expected to resist this change. The idea persists that big research teams boost scientific productivity, with postdocs offering the cheapest means of expansion.

Changing the scholarship system to non-tenured work contracts - comparable to postdoc fellowships in most developed countries - will mean losing roughly one-third of postdocs, assuming government funding stays the same. Even so, $96 \%$ of postdocs surveyed at the University of Minho support the change. A much bigger survey by the Portuguese National Association of Researchers in Science and Technology is expected to yield similar results.

International evidence indicates that reducing the number of postdocs by one-third is unlikely to impair productivity (see Nature 531, 263-265; 2016). Nuno Cerca University of Minho, Braga, Portugal. nunocerca@ceb.uminho.pt

\section{Postdoc rights need not hurt productivity}

Portugal's government is on the verge of a historic process, recognizing at last that postdoctoral researchers should have the same rights as the rest of the country's workforce 